\title{
LIFE THAT REALLY IS DOWN UNDER
}

by

C. Fliermans

E. I. du Pont de Nemours and Company Savannah River Laboratory

Aiken, SC 29808

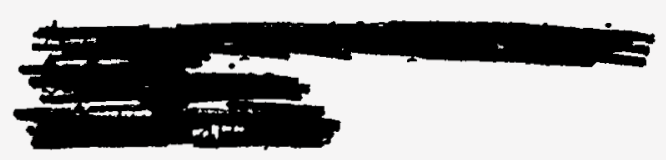

\section{REGEIVED \\ MAY 261998 \\ 0 बा}

\section{MASTEF}

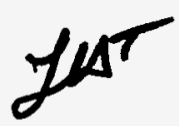

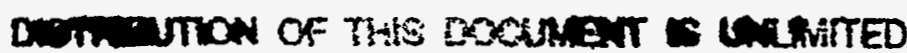

The information contained in this paper was developed during the course of work under Contract No. DE-AC09-76SR00001 with the U. S. Department of Energy. By acceptance of this paper, the publisher and/or recipient acknowledges the U. S. Government's right to retain a nonexclusive, royalty-free license in and to any copyright covering this paper, along with the right to reproduce and to authorize others to reproduce all or part of the copyrighted paper. 


\section{DISCLAIMER}

This report was prepared as an account of work sponsored by an agency of the United States Government. Neither the United States Government nor any agency thereof, nor any of their employees, makes any warranty, express or implied, or assumes any legal liability or responsibility for the accuracy, completeness, or usefulness of any information, apparatus, product, or process disclosed, or represents that its use would not infringe privately owned rights. Reference herein to any specific commercial product, process, or service by trade name, trademark, manufacturer, or otherwise does not necessarily constitute or imply its endorsement, recommendation, or favoring by the United States Government or any agency thereof. The views and opinions of authors expressed herein do not necessarily state or reflect those of the United States Government or any agency thereof.

This report has been reproduced directly from the best available copy.

Available to DOE and DOE contractors from the Office of Scientific and Technical Information, P.O. Box 62, Oak Ridge, TN 37831; prices available from (615) 576-8401.

Available to the public from the National Technical Information Service, U.S. Department of Commerce; 5285 Port Royal Road, Springfield, VA 22161. 


\section{DISCLAIMER}

Portions of this document may be illegible in electronic image products. Images are produced from the best available original document. 


\section{Life That Really Is Down Under}

by

Carl B. Fliermans, Ph.D.

Microbial Ecologist

Savannah River Laboratory

Aiken, SC

29808

The whirl of drill bits continually working their way southward into the internals of the earth's crust and the excitement of microbial ecologists are not familiar sounds to the sleepy community of Appleton, South Carolina. But then again, this is no ordinary drill rig seeking the aquifers below our feet. This rig and its team of investigators are probing the question, "Is there life down there?"

The 4-inch-wide hole drilled to a depth of 1750 feet in Allendale County, SC will never produce a pennies worth of gas or oil, nor a drop of water for drinking purposes, but has yielded a gusher of information for the scientific and industrial communities about the habitats and the microorganisms beneath our feet.

The story begins in the early 1980's, when Dr. Frank Wobber of the United States Department of Energy (DOE), recognized that fundamental science about deep aquifers (greater than 30 feet below the surface) was virtually non existent. If population centers were to continue to expand, the understanding of these deep reservoirs of life-giving water was essential.

Over $53 \%$ of the U. S. population receives its drinking water from wells, yet these sources continue to be polluted by government, industrial and 
private sources. If microorganism, life too small to be seen except through powerful microscopes, were present in the depths below our feet, then maybe they could help return polluted groundwaters to wholesome quality. Such was the vision in the Office of Health and Environmental Research at DOE that spawned the Microbiology of the Deep Subsurface Program.

But aren't the deep layers of the earth sterile and free of microorganisms? Isn't that why we can often drink from deep wells without fear of infection by some hazardous microorganism? That was certainly the thinking in the early part of the 20th century. Up until the early 1980 's, it was believed by the scientific community that life in abundance virtually ceased to exist below the root zone of plants. Before one thinks that an Andromeda Strain may be lurking behind the next sand grain or in the dense clay layers, it must be remembered that these organisms from the deep terrestrial subsurface have been brought to the surface ever since man has been drilling wells or mining minerals. Additionally, spray irrigation throughout the country has brought these microorganisms to the surface in an aerosolized form for decades without public health consequences.

Scientists working within the oil and natural gas industries believed that microorganisms were probably present at depth, but were never able to scientifically demonstrate that microbes found in these deep sediments were not carried down by the drilling operations.

That is in part why DOE funded such research. It was high risk! No one had done it before. No one believed that life existed to any great degree in the deep terrestrial subsurface, so why look?! 
The DOE program has shown life to be present and the excitement among the scientific and industrial community has literally been heard around the world.

The uniqueness of the drilling occurred when microbiologists associated with Savannah River Laboratory (a DOE facility run by the E. I. DuPont Co.) controlled the drilling procedures and the sampling conditions in four separate boreholes. In order to accomplish this research, the drilling operation had to be conducted under very exacting conditions.

Drilling was modified with patent pending samplers in order to collect the sediment material without chemical or biological contamination from drilling fluids, surface microorganisms or people involved in the drilling. During drilling, selected sediments were tagged with a variety of chemical tracers that could be detected up to one part in 100 trillion. Thus the microbiologists could determine the movement of water in the sediments and evaluate the effect of the drilling operations on the deep subsurface community.

To our great delight, the subsurface under the South Carolina Coastal Plain contained a great diversity and density of microorganisms. Thus, virtually every habitat on earth, in the oceans that surround us and now far under our feet contains life, microbial life.

Only when the temperature gets so high that liquid water can no longer exist, does life cease. "That means we have to start thinking about the possibility of finding life down to 9,000 feet, perhaps to 12,000 feet", says Dr. Bill Ghiorse a member of the microbiology team from Cornell University. It is now known for sure that life exists to depths of 1700 feet in the Coastal Plain sediments of South Carolina. 
Many surprises awaited the microbiologists as they probed the deep subsurface. One of the amazing things was the great diversity of microbial life and its activity. The deep subsurface in these coastal plain sediments teems with microbiological life. At each depth the microbial population was able to perform all the metabolic activities common on the earth's surface, yet they were totally different microorganisms.

The density and activity of these microorganisms was similar at 100 feet as it was at 800 feet, and even at 1700 feet. This was extremely exciting to the numerous scientists present when the samples were brought to the surface and analyzed. "It's a new frontier!" At each depth there was a complete change in the types of bacteria found. A completely different gene pool at each depth.

In spite of these changes in the types of microorganisms, all of the enzymatic functions were carried out at every depth. In other words, a complete physiological package exists in each sediment strata. All the roles were present, but the microbial players were different.

The organisms that have been found are tightly bound to the sediments. A gram of sandy sediments can contain 50 million bacteria, while only a 1000 are present in a gram of groundwater. Another interesting point is that the attached bacteria are far more diverse than their groundwater cousins.

This brings up a very interesting point. How in the world did these bugs get there? Good question! There are three hypothesis as to how the organisms got to these depths.

The first one suggests that the organisms were washed down into these depths over geological time or were deposited during the drilling operation. In these particular aquifers, the deeper sediments are under 
pressure like an artesian well so that microbes would have to swim against a very strong gradient. That's tough even for our beloved bugs! The extensive controls conducted during the drilling process indicates that the microorganisms were not deposited by drilling activities.

The second hypotheses states that the organism were brought in from the surface, or from a recharge area some 30 to 50 miles away. This hypothesis is also not tenable because these organisms are very tightly attached to the sand grains and the sediments and do not move horizontally very well.

The final hypothesis states that the organisms were trapped in the sediments at the time the sediments were laid down. Thus these organisms are in sediments that have been in place since the Cretaceous Period which is estimated to be around 100 million years ago. The current data seem to support this hypothesis since these organisms are well adapted to their environment in which they are found, and they are physiologically and genetically different from the organisms on the surface of the land. Dating studies on the microbes will shed more light on this enticing hypothesis.

Back in the laboratory, the researchers have been able to culture over $90 \%$ of the microorganisms seen in the sediments. This is most unusual, since the normal rate of recovery for surface soils is less than a few percent.

The group of microorganisms that have been isolated from these sediments are unusual in another regard. They are aerobic. Even at depths up to 1700 feet the organisms prefer to live in the presence of oxygen. This is not to surprising when one realizes that these habitats do contain small amounts of oxygen. 
Out of these sediments, scientists have isolated thousands of microorganisms that appear to be unique. What treasures do these microorganisms hold? If we have eyes to see, then these microorganisms will show us marvelous things about their habitat which is vital to those of us who walk the earth's surface.

These microorganisms are currently housed in a repository called the Subsurface Microbiology Culture Collection (SMCC). Pronounced, "smick". SMCC contains organisms never before described by the scientific community and hold potential for producing beneficial products for mankind.

Scientists are not sure all 3,300 microbes are new species, but the evidence is growing that many are. Approximately $90 \%$ of the organisms in SMCC are unidentifiable by standard biochemical techniques and have as yet escaped being identified by the probing taxonomists. DNA analyses indicated that the percentage of unidentifiable species may be even greater than we first thought. We will just have to wait until the research is in and that will take a number of man/years to complete.

A notice in The Commerce Business Daily (Sept. 1988), announced that the organisms will be made available through technology transfer to pharmaceutical, genetic engineering and food industries for screening the cultures for useful products. Such interest was spurred by the findings that microorganisms over the years have provided very useful products, i.e. antibiotics, for a number of industries. Cyclosporine, the lifesaving immune suppressing drug derived from a soil fungus found in Norway is but one example.

How important is this culture collection? "A single successful pharmaceutical product based on one of these organisms could easily make 
the Appleton hole as valuable as any oil well," says Dr. Jack Corey, Research Manager for the Environmental Science Division at Savannah River Laboratory.

Many of the pharmaceutical companies think so too. A number of the them showed up in September 1988 in Charleston, SC for an update on the DOE program.

SMCC is already drawing a great deal of attention from the industrial community. As stated by Dr. Jeff Paslay, Director of Chemical and Biological Screening for Upjohn Co., "We are always looking for unique species of microbes. The possibility that these organisms contain genes that have been lost as life evolved on the surface makes them very interesting."

"What we found is totally contrary to traditional thinking," says Dr. David L. Balkwill, a microbiologist at Florida State University. "We are seeing a whole new ecosystem that nobody realized was there."

The Department of Energy is concentrating on screening the organisms for the ability of these organisms to degrade and mineralize toxic compounds that are present in the groundwater beneath its facilities.

"We want to see if we can find better ways to clean up groundwater," says Dr. Frank J. Wobber, the Program Manager of DOE's subsurface initiative. Some experts believe that bioremediation may be the only economical way to clean up spills and contaminated aquifers, and the new microorganisms are being screened for these capabilities.

One hot prospect is the total degradation of trichloroethyelene, a degreasing solvent used in the metal finishing industry, dry cleaning establishments, movie industry, and electronic manufacturing. 
Other hazardous chemicals are likely to fall prey to the infallibility principle of microorganisms. This principle states that given enough time and the right conditions, microorganisms can degrade anything. Such may be the case for the microbes of SMCC.

"These organisms have enormous metabolic versatility; it appears that when they need to, they can grow on almost nothing," says Dr. David C. White, a University of Tennessee microbiologist who is working with The Savannah River Laboratory on the project. "They live in a very different environment than we have seen before, and they don't always play by the same rules."

Some of the benefits of this revolutionary research have come from very unsuspecting places, like NASA. As the U.S. prepares for an unmanned landing on Mars in 1994, the question of life on that planet has always been thought to be a possibility, but there has been no evidence to date. The past Viking mission collected samples from the surface of the Martian soil where the ultraviolet radiation is so intense that even the hardiest of microbes, as we know them, could not exist.

So what is so special about the Microbiology of the Deep Subsurface in relation to Mars? Well, if life exists hundreds and thousands of feet below the earth's surface maybe, just maybe, there is a chance that there is life in the subsurface of Mars where the microbes could live a protected life.

Who knows, but come 1994 we may find out, thanks to the DOE program.

This research has been a collaboration of some 15 different Universities and National Laboratories coordinated by Dr. Carl Fliermans, a microbial ecologist at Savannah River Laboratory who serves as the technical director and researcher for the Microbiology of the Deep Subsurface 
Investigation. "This is an exciting frontier, an advant-garde, if you will, in Microbial Ecology and Geological Research. The research has effectively extended the Biosphere deep into the Geosphere."

Many of the participating scientists have been stunned not only by the variety of organisms being found at such depths, but by their numbers. In some formations, hundreds of feet below the surface, these microbes are almost as plentiful as the microbes on the surface. Such densities and diversity will have an enormous effect on the geological process that are occurring in the subsurface of our planet. Thus the production of carbon dioxide and other metabolic products will enhance the formation of sediments and the mineralization process.

Recently Dr. Carl Fliermans and Dr. Jack Corey of the Savannah River Laboratory received Certificates of Appreciation from the Department of Energy. In presenting the awards Dr. Helen McCammon Director of the Ecological Research Division in the Office of Health and Environmental research said, "The Deep Probe program will probably be the most noteworthy program in DOE for the next 10 years. This program will make a real difference in how we handle waste in the subsurface from now on."

Within the next year, DOE officials plan to expand the project not only to new depths, but into drier, rockier geologic formations of the western part of the United States. These more hostile environments are expected to be pierced at DOE's Idaho National Engineering Laboratory and in the Columbia River Formation beneath its Hanford reservation in eastern Washington state.

We microbial ecologists have looked for and/or studied life in the thermal springs of the world, frigidness of the poles, the deep seas, thermal ocean vents and its sediments, dry desert sands, the moon and 
other planets. We had just about exhausted the places where we thought life existed and now an entirely new habitat for microorganisms opens below us

What an exciting time to be a microbial ecologist! 

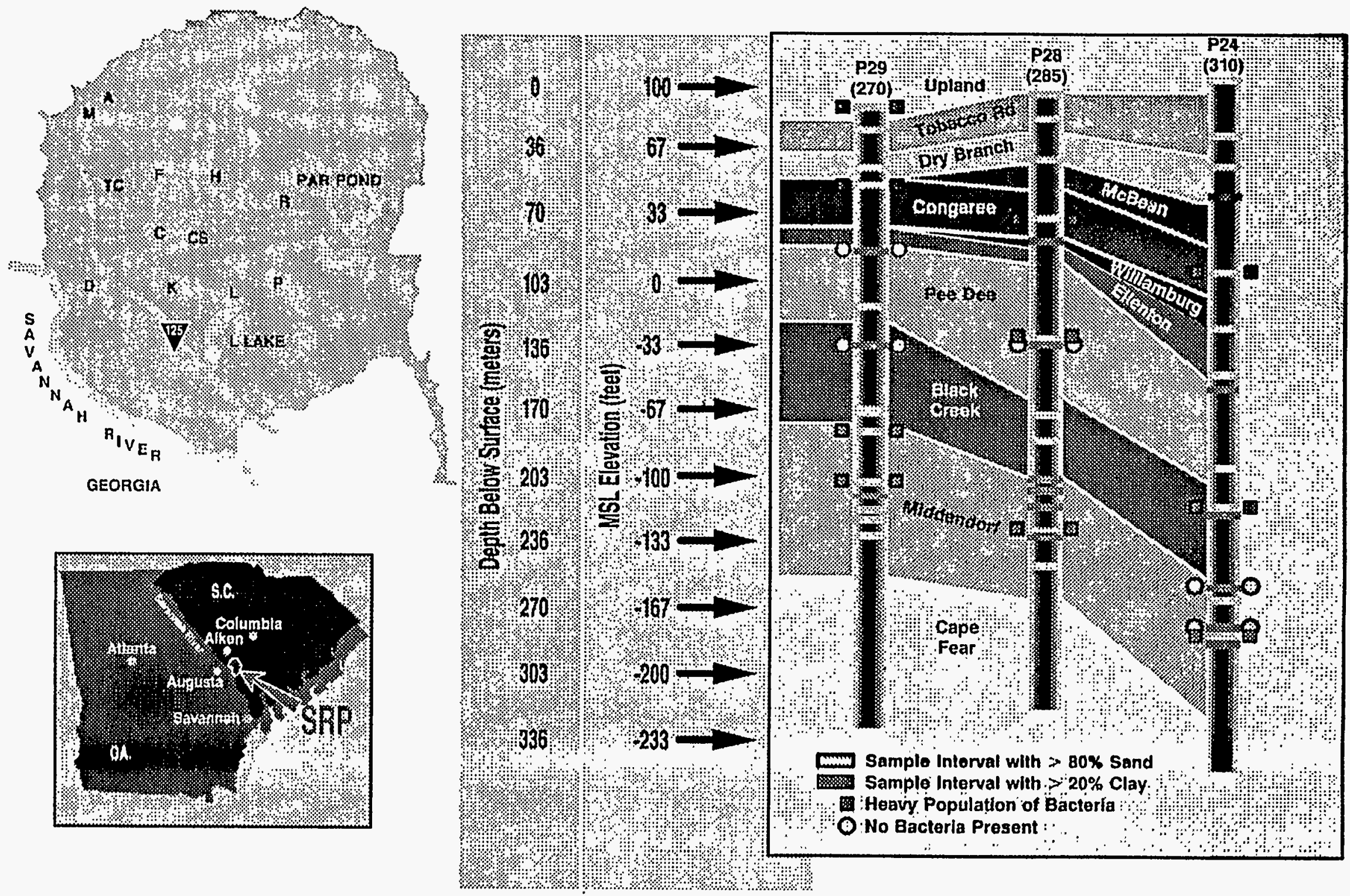

FIGURE 1. COMPOSITE PHOTOGRAPH SHOWING THE LOCATION OF THE INITIAL THREE BOREHOLES AT DEPARTMENT OF ENERGY'S SAVANNAH RIVER PLANT NEAR AIKEN, SOUTH CAROLINA. 


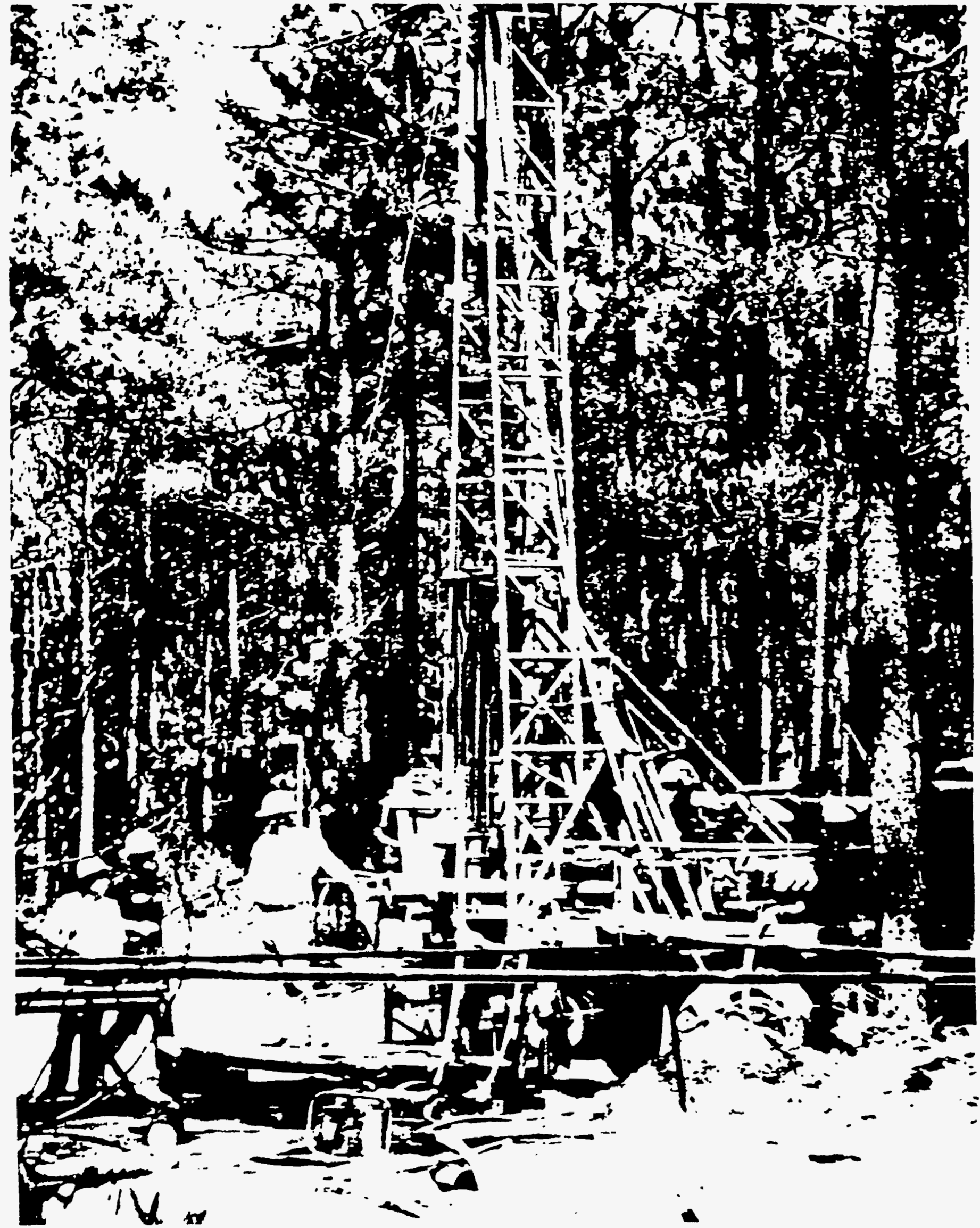

FIGURE 2. DRILLING RIG USED IN THE ASEPTIC SAMPLING OF MICROBIOLOGICAL SAMPLES HUNDREDS OF FEET BELOW THE SUBSURFACE. 


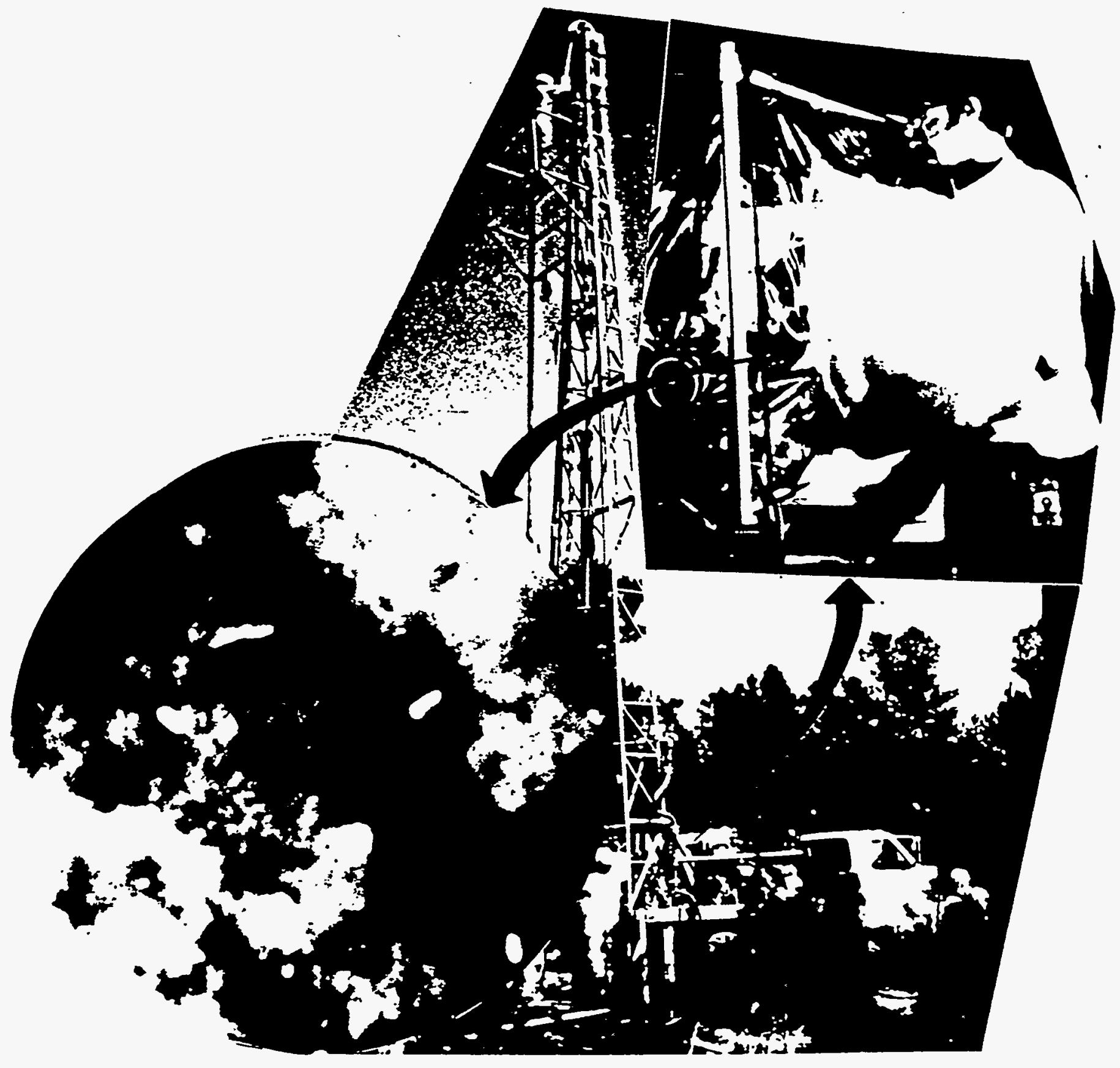

FIGURE 4. COMPOSITE PHOTOGRAPH OF THE DRILL RIG, ASEPTIC HANDLING OF THE MICROBIOLOGICAL SAMPLES IN THE STERILE TRANSFER BAG INSIDE A MOBILE LABORATORY AND A PHOTOMICROGRAPH OF BACTERIAL COLONIES COLLECTED ASEPTICALLY FROM 777 FEET. 


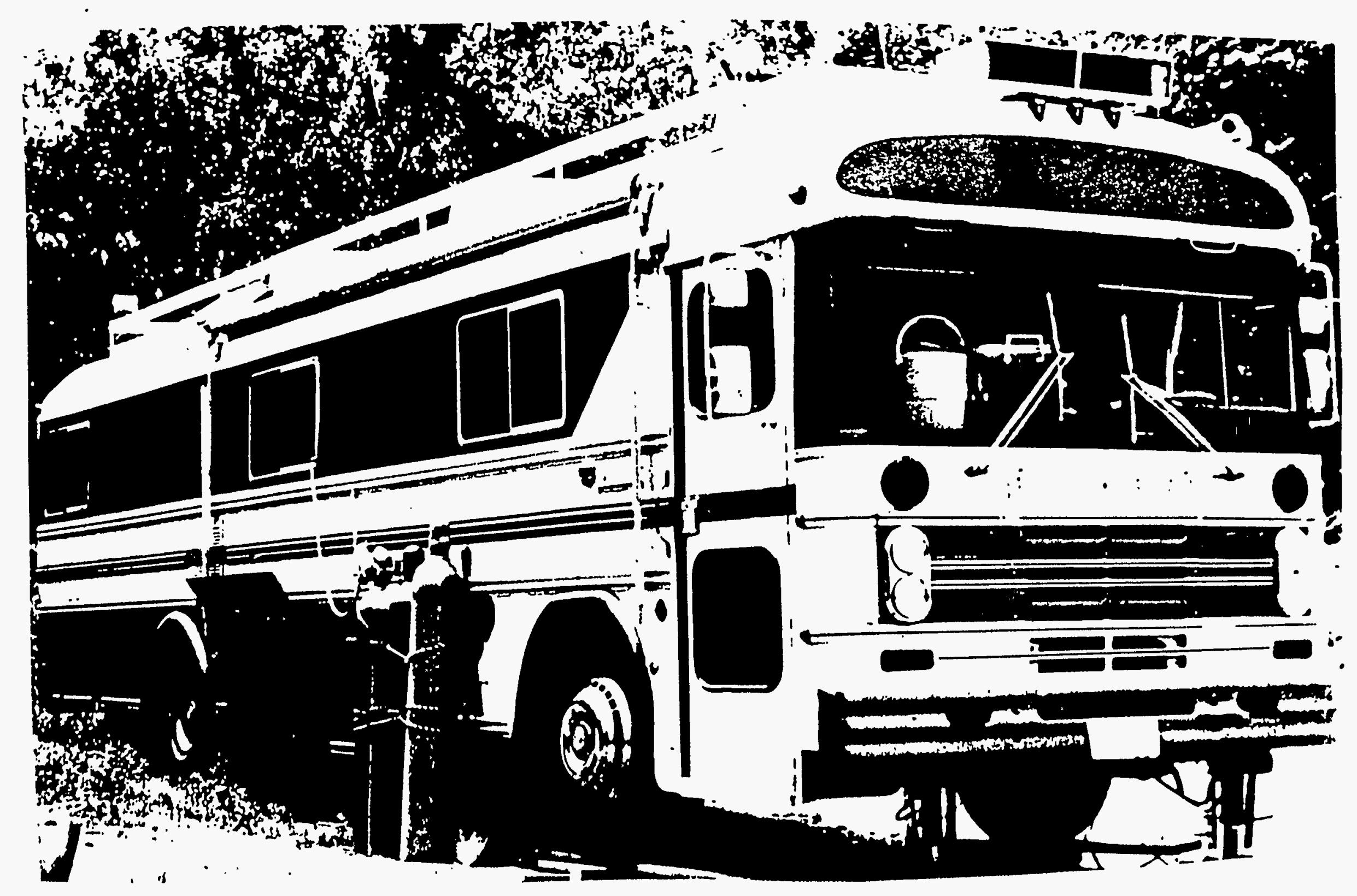

FIGURE 5. MOBILE MICROBIAL ECOLOGY LABORATORY (MMEL) USED IN THE PROCESSING OF SEDIMENTS SAMPLES FORM THE MICROBIOLOGY OF THE DEEP SUBSURFACE PROGRAM. SAMPLES WERE IMMEDIATELY BROUGHT TO THE MMEL AND PLACE IN A NITROGEN FLUSHED STERILE TD ANTEFR RAC FOR PROTFSCINS 


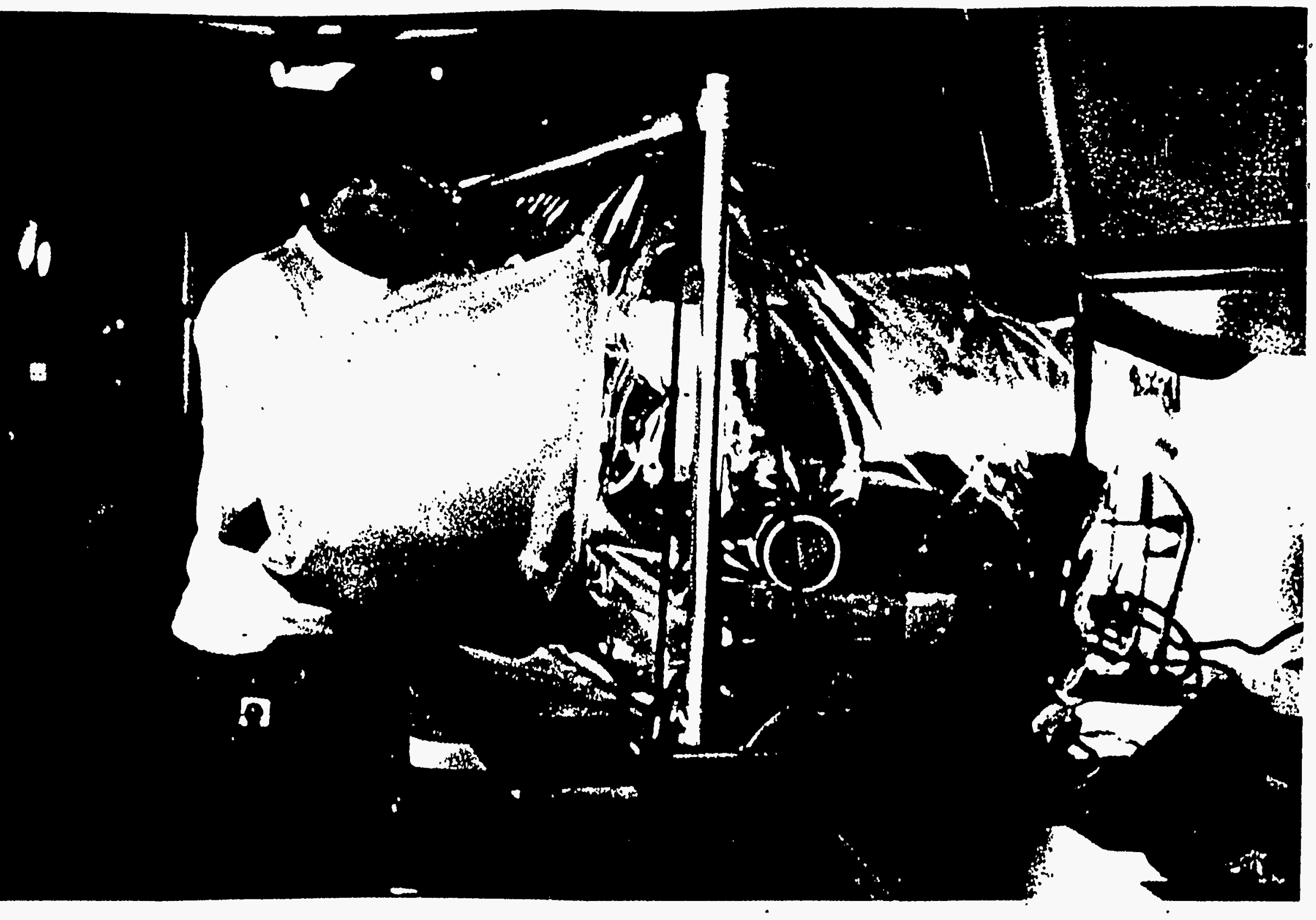

FIGURE 6. TECHNICIAN ASEPTICALLY PROCESSING THE SAMPLED SEDIMENT CORE INSIDE THE NITROGEN FLUSHED STERILE TRANSFER BAG LOCATED IN THE MOBILE MICROBIAL ECOLOGY LABORATORY. 


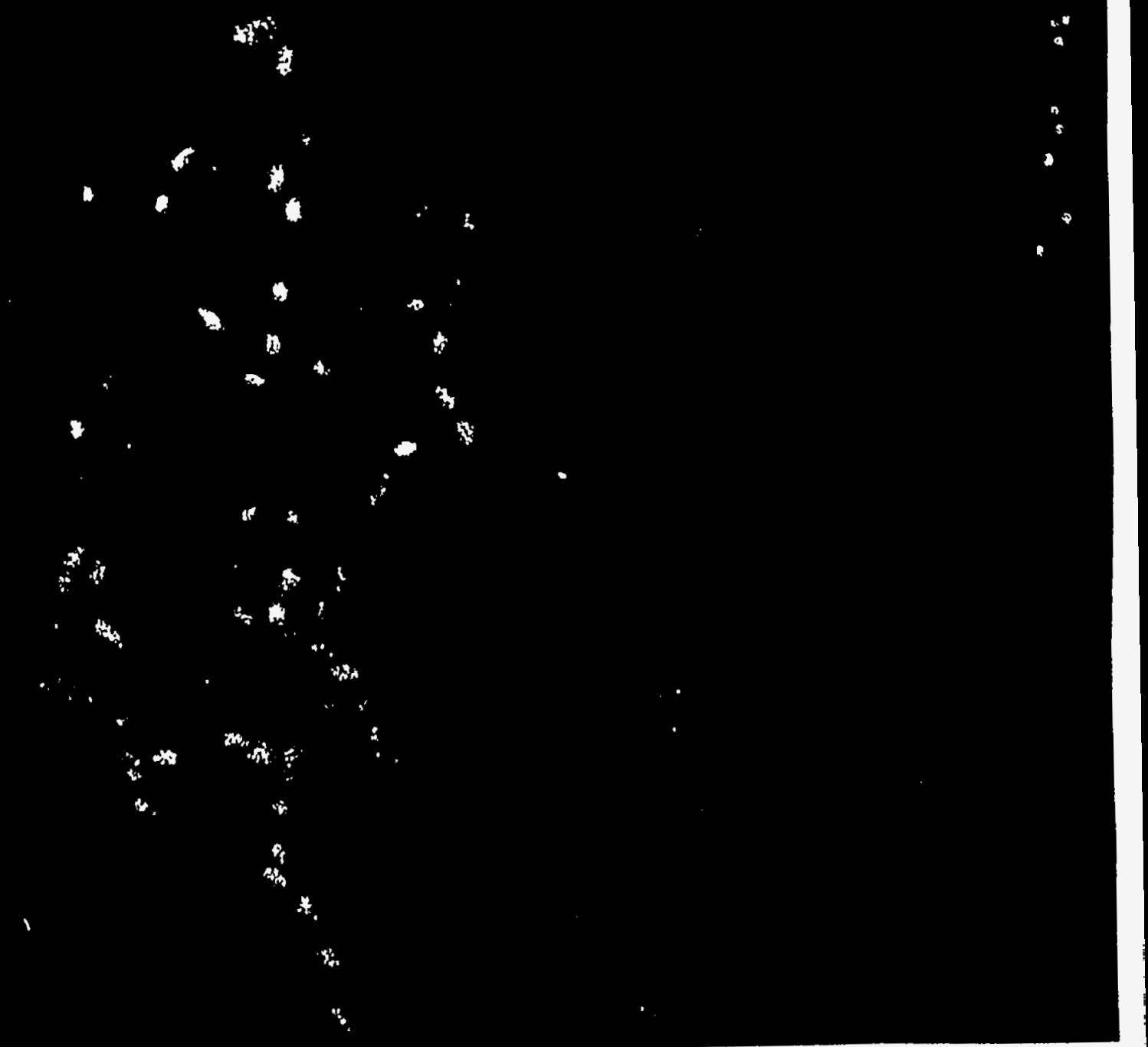

FIGURE 7. PHOTOMICROGRAPH OF BACTERIA ASEPTICALLY COLLECTED FROM A DEPTH OF 777 FEET AND STAINED WTTH ACRIDINE ORANGE. BACTERIA ARE A YELLOWISH-ORANGE IN COLOR AND DEMONSTRATE MORPHOLOGICAL DIVERSITY AND MICROCOLONY STRUCTURE ON THE SEDIMENT PARTICLES. IF 6000 OF THE LARGER BACTERIA WERE FITTED END THEY WOULD EXTEND A DISTANCE OF ONE INTH 




+\%००+\% +

FIGURE 8. DIAGRAMMATIC REPRESENTATION OF THE GEOLOGICAL FORMATIONS SAMPLED IN ONE OF THE BOREHOLES AT SAVANNAH RIVER LABORATORY. THE DENSITY OF BACTERIA ALONG WITH THE DIFFERENT METABOLIC TYPES OF MICROORGANISM PRESENT IN EACH OF THE FORMATIONS. 